October 1994

\title{
Bio-piracy: Creating Proprietary Rights in Plant Genetic Resources
}

James O. Odek

University of Nairobi

Follow this and additional works at: https://digitalcommons.law.uga.edu/jipl

Part of the Biotechnology Commons, Genetics Commons, Intellectual Property Law Commons, Plant Biology Commons, and the Plant Breeding and Genetics Commons

\section{Recommended Citation}

James O. Odek, Bio-piracy: Creating Proprietary Rights in Plant Genetic Resources, 2 J. INTELL. PROP. L. 141 (1994).

Available at: https://digitalcommons.law.uga.edu/jipl/vol2/iss1/4

This Article is brought to you for free and open access by Digital Commons @ University of Georgia School of Law. It has been accepted for inclusion in Journal of Intellectual Property Law by an authorized editor of Digital Commons @ University of Georgia School of Law. Please share how you have benefited from this access For more information, please contact tstriepe@uga.edu. 


\section{BIO-PIRACY: CREATING PROPRIETARY RIGHTS IN PLANT GENETIC RESOURCES}

\section{James O. Odek*}

Since the Age of Exploration, researchers and travellers have transported discovered plant species back to their own countries as new foods and raw materials for plant breeding. During expeditions to conquer and subjugate most of the developing countries, explorers screened agricultural materials for new and useful crops. The Great Columbian Exchange brought the tomato to Italian cuisine and introduced the potato to Ireland. ${ }^{1}$ The Royal Botanical Gardens at Kew benefited beyond measure from British travellers and colonialists in South America; indeed, the majesty of Britain as a colonial power in the eighteenth and nineteenth centuries was arguably due to the pre-eminence of the gardens. "[C]ontrol over plants often meant much wealth and power." ${ }^{22}$ The concept that exotic plant species found in nature were freely accessible to the taker commenced during this epoch. ${ }^{3}$

Presently, developing countries are passionately protesting that scientists from multinational corporations are prospecting for plant species in their tropical forests, protecting discoveries through breeders' rights, and merchandising the plants back to them at exorbitant prices." To developing countries, these practices constitute uncompensated exploitation of their "plant genetic resources" in the name of intellectual property rights. The increasing importance of plant biotechnology as a determinant of international competitiveness has fostered a challenge to the

\footnotetext{
* Lecturer of Public Law, University of Nairobi, Kenya; Advocate, High Court of Kenya; LL.B., 1987, University of Nairobi; Diploma of Law, 1988, Kenya School of Law; LL.M., 1989, Yale Law School; S.J.D. Candidate, University of Toronto.

${ }^{1}$ Rebecca L. Margulies, Note, Protecting Biodiversity: Recognizing International Intellectual Property Rights in Plant Genetic Resources, 14 MiCH. J. INT'L L. 322, 328 (1993).

2 Lawrence Busch et al., Plants Power, and Profit: SOclal, ECONOMic, and ETHICAL CONSEQUENCES OF THE NEW BIOTEChNOLOGIES 59 (1991).

' Margulies, supra note 1, at 328.

- See Calestous JUMa, THE Gene huNTERS: Biotechnology aNd THE SCRAMble for SEEDs 169-170 (1989) (observing that industrialized nations collect and "improve" Third World resources before selling such resources back at high prices).
} 
concept of free access to plant genetic resources by developing countries.

An analysis of plant breeders' rights is incomplete without scrutiny of the ownership and legal status of the plant genetic resources crucial to the sustenance of plant biotechnology. Yet an inquiry into ownership is deficient without a discussion of the issue of dominion over plant germplasm in gene banks. As a corollary to this issue, questions of compensation, access, and genetic bio-piracy become germane.

At the heart of these issues lie two equitable considerations. The first consideration is whether developing countries should pay for new plant varieties developed by Western seed companies from species obtained from the Third World. ${ }^{5}$ The second factor is whether plant genetic resources should be commodities, and if so, who should have proprietary rights?

This Article offers an analysis of these issues and addresses the following issues: (1) the nature of plant genetic resources; (2) the significance of these resources; (3) the role the concept of a "common heritage of mankind" plays in justifying the uncompensated extraction of plant genetic resources; (4) the extent to which developing countries stand to gain from making elite plant genetic resources subject to a concept of a common heritage of mankind; (5) the cases for and against commoditization of plant genetic resources; (6) the resolution of the question of ownership of plant genetic resources; (7) the extent to which the Biodiversity Convention and Agenda 21 address ownership of plant genetic resources; (8) possible proposals to resolve the legal status of plant genetic resources; and (9) entities in which proprietary rights over plant genetic resources could be vested.

\section{Significance of Plant Genetic Resources}

Scientifically, the term "plant genetic resources" refers "to the genetic information found in the chromosomes of the nucleus and

' See Bill Paul, Third World Battles for Fruit of Its Seed Stocks, WALl ST. J., June 15, 1984, at 34 (characterizing dispute between developing countries and Western seed companies as "seed wars"). 
associated subcellular structures of plants;"; the chemical chromosomal information carried in gene alleles of living plant cells. ${ }^{7}$ This genetic material is found in every living cell of every plant. Plant genetic resources include genetic material from "all agricultural crops, fruit, nut and forest trees, forage crops, medicinal and ornamental plants, unexploited plants, wild relatives and ecosystem diversity. ${ }^{\text {}}$ These resources are divided into primary, secondary and tertiary gene pools. ${ }^{9}$

The economic significance of these resources exists in their potential value to industry, medicine, ${ }^{10}$ agriculture, and energy development. ${ }^{11}$ In medicine, for instance, the rosy periwinkle of Madagascar has yielded two compounds used to treat Hodgkin's disease and juvenile leukemia successfully. ${ }^{12}$ A vine, Ancistro cladus korupensis, with enormous potential for treatment of AIDS, has been found in the Korup forest of Cameroon. ${ }^{13}$ In agriculture, scientists expect genetic engineering to increase efficiency and productivity and to improve the nutritional quality of food. ${ }^{14}$ The development of insect-resistant crops, through agricultural biotechnology, may minimize dependence on chemical pesticides. ${ }^{15}$ These genetic resources make significant contributions to climate

- H. Garrison Wilkes, Plant Genetic Resources Over Ten Thousand Years: From a Handful of Seed to the Crop-Specific Mega-Genebanks, in SEEDS AND SOVEREIGNTY: THE UsE AND CONTROL OF PLANT GeNETIC ResourCes 67, 79 (Jack R. Kloppenburg Jr. ed., 1988).

"See id. (discussing early use of "specimen" plants).

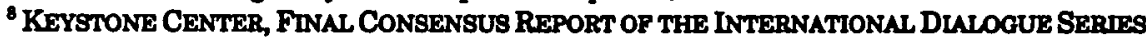
on Plant Genetic Resources, Madras PlenNary Session 8 (1990) thereinafter Keystone Center, Madras Session].

- Primary resources denote the commercial cultivars, both obsolete, current and newly developed; secondary resources denote folk (indigenous) varieties; tertiary resources denote the wild and weedy plant varieties. Id.

${ }^{10}$ See Margulies, supra note 1, at 325 (noting that, of drugs sold in the United States since the $1960 \mathrm{~s}, 25$ percent derived from plant sources).

11 See David E. Bell, The 1992 Convention on Biological Diversity: The Continuing Significance of U.S Objections at the Earth Summit, 26 GEO. WASH. J. INT'L L. \& ECON. 479, 484 (1993) (discussing value of species diversity).

${ }^{13}$ Birds and Bees, ECONOMIS, May 10, 1992, at 15, 17.

is AIDS, NEW AFRICAN, January, 1994, at 22.

14 See Karen G. Hermann, Issues in the Regulation of Bioengineered Food, 7 HIGH TECH. L.J. 107, 109-11 (1993) (noting examples of "antisense" tomato which is less prone to bruising and canola oil containing higher percentage of unsaturated fatty acids).

${ }^{26}$ Karen A. Goldman, Note, Compensation for Use of Biological Resources Under the Convention on Biological Diversity: Compatibility of Conservation Measures and Competitiveness of the Biotechnology Industry, 25 LAW \& POL'Y IN INT'L BUS. 695, 703 (1994). 
stabilization, watershed and soil protection, and maintenance of the earth's chemical balance. ${ }^{16}$ Bioremediation, the use of specialized organisms to clean up pollution or environmental waste, is another area in which plant genetic resources can help protect the environment. ${ }^{17}$

Of the vast number of plant species in existence, it is probable that only a small percentage have been identified, and of those identified, relatively few plant species have been studied in depth. $^{18}$ In monetary terms, these resources make immense contributions to economies of developed countries. For example, in the United States plant genetic resources from developing countries contribute $\$ 500$ million per year to the wheat crop. ${ }^{19}$

Because of plant genetic resources' significance, both developed and developing countries have shown concern over their control. This attention has increased as the public and private sectors, principally in the developed countries, ${ }^{20}$ have pursued heavily funded bio-technological research programs. ${ }^{21}$ To developing countries, the escalating flow of genetic material and information from the gene-rich but technology-poor countries of the South to the gene-poor but technology-rich countries of the North has heightened the interest in these resources. In recent years, developing countries have realized that the capacity to utilize and manipulate plants' genetic information is an important factor in international competitiveness. ${ }^{22}$ Consequently, ownership and control of these resources is becoming a critical element of developing countries' trade policies.

${ }^{16}$ U.N. ENVIRONMENT PROGRAMME, BIODIVGRSITY COUNTRY STUDIES: SYNTHESIS REPORT, at 1, U.N. Doc. Country Studies/Inf. 1 (1992).

${ }^{17} \mathrm{Id}$.

${ }^{18}$ Norman Myers, Genetic Resources in Jeopandy, 13 AMBIO 171 (1984).

${ }^{19}$ ALBERT SASSON, BIOTEChNOLOGIES AND DEVELOPMENT, UNESCO, TECHNICAL CENTRE FOR AGRICULTURAL AND RURAL COOPERATION 296 (1988); PAT R. MOONEY, THE LAW OF THE SEED-AN INTRODUCTION 77-78 (1984).

${ }^{20}$ See BUSCH ET AL, supra note 2, at 17-20 (tracing commercial developments in biotechnology).

${ }^{21}$ Keystone Center, Final Consensus Report: Global IntTlative for the Security and Sustannable Use of Plant Genetic Resources, Oslo Plentary Session 11 (1991) [hereinafter KEYSTONE CENTER, OSLO SESSION].

${ }^{22}$ JACK R. KLOPPENBURG JR., FIRST THE SEED 152 (1988). 


\section{BIO-PIRACY AND UNCOMPENSATED EXTRACTION OF PLANT GENETIC RESOURCES}

Plant genetic resources from developing countries have largely been appropriated without compensation. ${ }^{23}$ Most developing countries have characterized this uni-directional and uncompensated appropriation as "bio-piracy." Piracy, however, is a nebulous expression lacking a precise legal definition. ${ }^{24}$ Because international law has not defined the uncompensated extraction of plant genetic resources as piracy, the characterization of such acts as piracy serves as a normative assertion by developing countries that they have an entitlement to their plant genetic resources. ${ }^{25}$

In the contemporary era, discrete examples from Africa ${ }^{26}$ and India illustrate the uncompensated extraction of plant genetic resources from developing countries. Roy Laishley observed:

[Kenya] is bringing in tropical legume seeds developed in Australia which were based on indigenous Kenya seeds. Therefore at least a portion of Kenya's new grass and legume seeds have been commercially imported at some cost to the country. However, there is no record of Kenya having received any payment for the raw material ... which developed the new varieties. ${ }^{27}$

Erna Bennett of the Food and Agriculture Organization (FAO) of

\footnotetext{
${ }^{23}$ See Jack R. Kloppenburg Jr. \& Daniel L. Kleinman, Seeds of Controversy: National Property Versus Common Heritage, in SEEDS AND SOVEREIGNTY: THE USE AND CONTROL OF PIANT GeNETIC ResouRCes 171, 173 (Jack R. Kloppenburg Jr. ed., 1988) (setting forth framework for achieving "global plant genetic interdependence").

${ }^{24}$ "In the broadest sense, [piracy] can signify any unauthorized and uncompensated reproduction or simulation of a creative intellectual product that deprives the originator of the economic or moral benefits accruing from his or her creative undertaking." $J$. $H$. Reichman, Intellectual Property in International Trade: Opportunities and Risks of a GATT Connection, 22 VAND. J. TransNaT'L L. 747, 775 (1989).

${ }^{25}$ In positive international law, piracy is a term for robbery committed on the high seas outside the territorial jurisdiction of any state. In re Piracy Jure Gentium [1934] App. Cas. $586,589$.

${ }^{28}$ See Richard Stone, The Biodiversity Treaty: Pandora's Box or Fair Deal?, 256 ScIENCE 1624, 1624 (1992) (citing example of rosy periwinkle from Madagascar).

${ }^{27}$ MOONEY, supra note 19, at 30.
} 
the United Nations narrated a similar account of an uncompensated extraction of plant genetic resources from Libya, where forage seed has been exported free of charge to Australia and has been reimported, in a slightly different form, at commercial prices. ${ }^{28}$

Another example of uncompensated extraction of plant genetic resources from Africa involves the Endod (Phytolacca dodecandra) tree, commonly known as the African soapberry plant. This plant is a perennial that has been cultivated for centuries in Africa, particularly in Ethiopia, where it is used as a laundry soap and shampoo. In 1990, the University of Toledo applied for a patent on the use of Endod to control Zebra mussels. ${ }^{29}$ Royalties from this patent, however, will not go to the plant's original "proprietors," the Ethiopian people, who selected, nurtured and preserved Endod for centuries. $^{30}$

A similar story involves the neem tree and its products, used for centuries in India as a biopesticide and medicine. ${ }^{31}$ In developed countries, neem-based products for medicine and bio-insecticides are currently patented, but the Indian growers of the neem tree have not received any royalties for protecting and conserving this tree. $^{32}$

Another case of uncompensated extraction includes the Monellin and Thaumatin plants. African farmers have used these plants as sweeteners and flavor enhancers for centuries. The United States, which has issued patents for products of these plants, contains a $\$ 900$ million per year market for low-calorie sweeteners, but the African farmers who have preserved this plant are not the holders

${ }^{28}$ Id.

20 This patent raises the issue of second use. Suppose a product is already known for one biological application, but a different biological utility is discovered. Is the second use patentable? Under European laws, a patent can issue for the second use. See, e.g., R.S. CRespi, PATents: A Basic GuIDe to PATENTING In BIOTEChanology 65 (1988) (providing example of "second use" in treatment of senility with drug nimodipin).

${ }^{20}$ See Endod: A Case Study of the Use of African Indigenous Knowledge to Address Global Health and Environmental Problems, RAFI CoMmuNIQUE, (Rural Advancement Found. Int', Ottawa, Ontario), Mar. 1993, at 1 (explaining Ethiopians' use of endod).

al Vandana ShIVA, Monocultures of the Mind: UNDERstanding THE THREATs to Biological aNd Cultural Diversity 7, 18 (1993).

${ }^{2} I d$. (describing traditional Indian use of neem and uncompensated extraction of neem by Western companies). 
of the patent. $^{33}$ Finally, Eli Lilly and Co. has made millions of dollars on the sale of the anticancer drugs vinblastine and vincristine, extracted from the rosy periwinkle plant, without any compensation to Madagascar, its country of origin. ${ }^{34}$

These examples of uncompensated extraction of plant genetic resources raise a fundamental issue regarding "secondary use" of a product. Using the Endod case as an illustration, what argument supports the Ethiopian rights against the patenting of Endod by the University of Toledo? If one adopts a European, individualistic concept of patent property, the Ethiopian people have little chance of invalidating the Endod patent. Under European patent laws, the Endod case involves a new use of an old product. The University of Toledo would probably argue that the Endod patent does not involve a use analogous to the Ethiopians' use of Endod as a soap and shampoo. Thus, the Endod patent is valid because a patent for a new use of a known substance is supportable if the new use involves practical difficulties which the patentee has been the first to see and overcome by his own ingenuity. ${ }^{35}$

The inventiveness of the Endod patent-the idea of using Endod to control Zebra mussels-further weakens the Ethiopian case. As Justice Graham stated in Olin Mathieson Chemical Corp. $v$ Biorex Ltd. : $^{36}$

[T]he invention may lie in the idea of taking the step in question. Why should anyone want to take this step unless he had first appreciated that such a step might give him a useful product?.... [I]t is in my judgement not obvious to take the step in question unless and until it has been conceived that the idea of doing so might lead to a useful result. ${ }^{37}$

\footnotetext{
${ }^{3}$ Scientista from Lucky Biotech and the University of California received U.S. Patent No. $5,234,834$ for all fruit, seeds and vegetables genetically engineered to contain super-8weet natural proteins from monellin and thaumatin (Thaumatococcus daniellii). U.S. Patents Awarded on Materials Derived from African Plants: Monellin and Thaumatin, RAFI COMMUNIQUE, (Rural Advancement Found. Int', Ottawa, Ontario), Dec. 1993, at 2.

s4 Goldman, supra note 15 , at 717 (citation omitted).

${ }^{36}$ DOUglas Falconer eT AL., TERRELL ON THE LAW OF PATENTS \& 316, at 129 (12th ed. 1971).

${ }^{36} 1970$ R.P.D. \& T.M. 157 (Eng. Ch.).

${ }^{37}$ Id. at 192.
} 
This requirement of an "inventive step" is disadvantageous to developing countries. It affords little leeway in which developing countries can make their claims, ${ }^{38}$ Moreover, "[n]ative people face a legal system that divides the world up in a fashion both foreign and hostile to their sense of felt need. ${ }^{39}$ At almost every level, a developing country's claims fall outside the parameters of western legal discourse. ${ }^{40}$

What facilitates the uncompensated extraction of plant genetic resources? The international classification of such resources as part of a "common heritage of mankind," a universal resource immune to private property claims, expedites the uncompensated removal of plant genetic resources. ${ }^{41}$ Any material falling in this category is in the international public domain. Subject to the costs of collection, the materials in this domain are freely accessible.

The International Convention for the Protection of New Varieties of Plants (UPOV Convention) endorses the treatment of plant genetic resources as part of a common heritage. Under the UPOV Convention, breeder's rights accrue whatever the origin, "artificial or natural," of the initial variation from which the variety was derived. ${ }^{42}$ By using the term "natural," the UPOV Convention adopts this concept of a common heritage of mankind.

Developing countries object to the classification of their plant genetic resources as a common heritage. Norah Olembo has noted that:

${ }^{38}$ Cf. Rosemary J. Coombe, The Properties of Culture and the Politics of Possessing Identity: Native Claims in the Cultural Appropriation Controversy, 6 CAN. J.L. \& JURISPRUDENCE 249, 268-269 (1993) (arguing that law is not coterminous with assertions of cultural presence).

${ }^{89}$ Id. at 269 (citation omitted).

$\omega$ Id. (emphasizing demarcation between "ideas and expressions, oral traditions and written forms").

"The common heritage principle has "gained universal acceptance in areas, such as the deep sea-bed, the lunar surface, Antarctica, which fall outside of the jurisdiction of any one state and not yet subject to extensive exploitation." Margulies, supra note 1, at 330; see also Simone Bilderbeek, The Common Heritage Principle and the World Heritage Principle, in BIODIVERSITY AND INTERNATIONAL LAW (Simone Bilderbeek ed., 1992) (attributing first articulation of principle to Argentine ambassador to the United Nations during negotiations on lunar surface).

2International Convention for the Protection of New Varieties of Plants, Dec. 2, 1961, art. 6, 33 U.S.T. 2703, 815 U.N.T.S. 112. 
The concept of free access to genetic material is noble, and in the past, has assisted developing countries to acquire materials from the CGIAR centers for their food programs. But what will happen if plant material is obtained by a developed country company from the CGIAR centers, is genetically improved, and then protected through patents? This protected, modified form of plant material would then be accessible to the original country at a cost. So what went out free, would return with a price tag .... 49

Disapproval of a common heritage and free access is echoed by Vandana Shiva, who contends that ideas from developing countries travel freely to developed countries, while "[i]deas from the North-even when originally derived from indigenous knowledge of the Third World farmers and herbalists-are protected by [i]ntellectual [p]roperty [r]ights."

Conceptually, the uncompensated extraction and subsequent patenting of plant biotechnological products from developing countries means that these resources become commoditized and sold as new and improved varieties to these countries. In this process of commoditization, these resources enjoy a unique distinction. They are considered a common heritage of mankind, humanity's collective genetic estate, available as a free good ${ }^{45}$ subject to the expenses of collection. ${ }^{46}$ This approach leaves plant genetic resources in a jurisprudential void, unprotected by private property rights and freely accessible to all. ${ }^{47}$ This free access is a source of international dispute.

4 International Experts Debate Patents and Biodiversity Issues, CGIAR HIGHIGHTs, (CGIAR, Washington, D.C.), Feb. 1994, at 4.

"SHIVA, supra note 31, at 12-13.

${ }^{45}$ Angus J. Wells, Patenting New Life Forms: An Ecological Perspective, 3 EUR. INTEL. PROP. REV. 111, 114 (1994).

${ }^{46}$ KLOPPENBURG, supra note 22 , at 166.

${ }^{47}$ But see Margulies, supra note 1, at 331 (characterizing efforts to deny private property rights in plant germplasm as "doomed from the start"). 


\section{ACCess to Plant Genetic Resources}

Developing countries contend that unfettered access to their plant genetic resources by developing countries is tantamount to exploitation. ${ }^{48}$ They insist that if their plant genetic resources are part of a common heritage of mankind, then all elite commercial varieties derived from these resources in developed countries should be similarly classified. ${ }^{49}$ This argument amounts to a demand for the de-commoditization of elite commercial varieties. ${ }^{.0}$ The FAO's International Undertaking on Plant Genetic Resources (FAO Undertaking), ${ }^{51}$ based upon the principle that plant genetic resources are a common heritage of mankind which includes both elite and current breeders' lines of plant species, embraces this demand. ${ }^{52}$

Developed countries have rejected the inclusion of elite plant species in a common heritage of mankind. These countries have expressed reservations about provisions that threaten breeders' rights. $^{\text {BS }}$ As a result of relentless lobbying from developed countries, succeeding FAO Conferences have reversed the inclusion of elite species in a common heritage. ${ }^{.4}$ In two resolutions that are now annexed to the FAO Undertaking, the FAO recognized that plant breeders' rights are not incompatible with the Undertaking. ${ }^{65}$

It is pertinent to question the extent to which developing countries stand to benefit from the categorization of elite plant genetic resources as part of a common heritage of mankind. Developing countries would gain to the extent that such a classifi(1983).

Gerald Dworkin, The Plant Varieties Act, 1983, EUR. INTELl, PROP. REV., 270, 272

'KLOPPENBURG, supra note 22, at 172.

${ }^{60}$ Kloppenburg \& Kleinman, supra note 23, at 174.

${ }^{81}$ International Undertaking on Plant Genetic Resources, REPORT OF THE COUNCL of FAO, at IT 71-75, U.N. Doc. C84/REP (1983) thereinafter FAO Undertaking].

Id.; Kloppenburg \& Kleinman, supra note 23, at 174.

6s Kloppenburg \& Kleinman, supra note 23, at 191 (eiting example of U.S. State Department's claim that FAO Undertaking precluded by domestic legislation recognizing plant breeders' rights).

4 KeYstone CENTER, OsLO SESSION, supra note 21, at 9 (observing that resolutions recognize that FAO Undertaking not incompatible with plant breeders' rights).

${ }^{5}$ FAO Undertaking, supra note 51, at I 72. 
cation would ensure free access to improved plant varieties which were previously available only upon payment of royalties. This classification would place both developed and developing countries on a formally even footing.

However, formal "equality of access ${ }^{\text {nbs }}$ does not entail equivalence in the distribution of benefits between developed and developing countries. Developed countries propagate elite plant varieties for application in intensive agricultural production systems supported by capital and other inputs. ${ }^{67}$ These sophisticated varieties are often designed by industrialized nations that can meet the energy-intensive demands of this type of agriculture. ${ }^{68}$ These technologically refined seeds are simply ill-suited to the needs of most developing countries. ${ }^{69}$ Consequently, free access to improved varieties does not necessarily enable developing countries to productively use these varieties.

In addition, given their geopolitical power, multinational seed companies are unlikely to dismantle the institutional arrangements which provide private proprietary rights in improved plant genetic resources. These corporations will seek to perpetuate these rights. ${ }^{60}$ Thus, developing countries may encounter obstacles in extending the concept of a common heritage to elite plant varieties.

Although the developing countries hold a position that is tenable in equity, their demands are misplaced. The real difficulty facing developing countries is not access to plant genetic resources-these resources are in large supply in their backyards. The problem is establishing control and utilizing these resources. Genuine control of genetic resources lies in knowing exactly what the resources are, and how they can be manipulated. ${ }^{61}$ It is in these areas that developing countries lack adequate control, and it is in these areas that their efforts should be directed. ${ }^{62}$ Otherwise, uncompensated

Kloppenburg \& Kleinman, supra note 23, at 192.

${ }^{67}$ See generally id. at 193-94 (contending that access to South's genetic resources not adequately compensated by access to developed gene lines of little value to South).

SB Margulies, supra note 1, at 331.

${ }^{60}$ Kloppenburg \& Kleinman, supra note 23, at 192.

${ }^{\infty}$ Id.

11. at 194, 198.

a See id. at 198 (acknowledging that developing countries must master their genetic resources if institutional mechanisms such as international plant gene fund are to succeed). 
germplasm extraction will continue because "[t]he real issue that is never addressed is the role of scientific ignorance as the necessary and sufficient condition for the exploitative appropriation of the plant genetic resources ${ }^{\text {} 63}$ of the Southern countries.

The issue is not ownership of the gene but possession of the technology to utilize genes in a particular environment. On this matter, Garrison Wilkes contends that "the fundamental cause of concern about who owns the plant genetic resources is the developing nations' lack of capability with regard to plant breeding and the new biotechnologies which might permit them to offset the power of transnational seed companies and institutional support for plant breeders' rights. ${ }^{\text {64 }}$ Unless the gene-rich but technology-poor developing countries begin to consider basic and applied biological research as an essential development goal, they shall continue to relinquish their botanic genetic resources to the gene-poor but technology-rich developed countries. ${ }^{65}$

Developed and developing countries have conflicting perspectives on access and ownership of plant genetic resources. This conflict has given rise to the phenomenon known as the "seed wars." At the heart of these wars lies the equitable question of whether developing countries should pay for new seed varieties developed by Western seed companies from seeds obtained in the Third World. ${ }^{67}$ The cases for and against payment by the developing countries are equivalent to the cases for and against commoditization of plant genetic resources. Similar arguments address the question of whether plant genetic resources ought to continue as a common heritage of mankind. These arguments strike at the heart of the concept of property, particularly Locke's labor theory of property.

${ }^{68}$ Daniel J. Goldstein, Molecular Biology and the Protection of Germplasm: A Matter of National Security, in SEEDs AND SOVEREIGNTY: THE USE AND CONTROL OF PLANT GENETIC RESOURCES 315, 318 (Jack R. Kloppenburg Jr. ed., 1988).

Wilkes, supra note 6 , at 87.

${ }^{65}$ Some developed countries insist that all basic science is an expensive luxury, and therefore have successfully insisted that developing countries avoid basic research. $C f$. BUSCH ET AL., supra note 2, at 183 (pointing out that few developing countries have "critical mass" of scientists required for genetic engineering research).

${ }^{6}$ Neil D. Hamilton, Who Owns Dinner: Evolving Legal Mechanisms for Ownership of Plant Genetic Resources, 28 TULsA L.J. 601, 602 (1993).

${ }^{67}$ Paul, supra note 5, at 34. 
Developed countries advance three arguments against commodization of plant genetic resources and in support of a common heritage concept. ${ }^{68}$ Such arguments implicitly rely on the Lockean labor theory of property. ${ }^{60}$ Focusing primarily on maintaining access to undeveloped plant genetic resources and shielding the grant of intellectual property rights in technology, these arguments hypothesize that to make it worthwhile for enterprises to develop new plant varieties, a solid plant breeders' regime is indispensable. These arguments must be critically appraised.

Developed countries argue that plant genetic resources intermittently contain valuable genes. Until a particular accession is evaluated and its traits identified, the resources it contains are of an unknown value. ${ }^{70}$ For example, a representative of one leading American seed company has stated that "raw germplasm only becomes valuable after considerable investment of time and money, both in adapting exotic germplasm for use by applied plant breeders and in incorporating the germplasm into varieties useful to farmers."71

This argument contains three flaws. First, as Robert Nozick asks, why should a person gain what he mixes with his labor instead of losing his labor? ${ }^{72}$ In the context of plant genetic resources, why should developed countries gain the entire proprietary right to a new variety by mixing their intellect with plant genetic resources from developing countries? Why should developing countries lose their genetic resources? No philosophical reasoning justifies developed countries gaining the "whole" by mixing their labor with a significant "part" supplied by developing

William A. Stiles Jr., A Congressional View on Proprietary Rights, in INTELLECTUAL PROPERTY RIGHTs Assoctated wTTH PLANTS 35, 44 (American Soc'y of Agronomy No. 52, 1989) (observing that many developed countries contend germplasm resources' value attributable to scientific improvement).

${ }^{\infty}$ Locke, in his treatise on government, formulated the labor theory of property. To enjoy goods, an individual must exert labor upon them. This labor adds value to the goods. The "value" added by the individual bestows property rights upon the laborer. JOHN LOCKE, TwO TREATISES OF GOVERNMENT 208-09 (Peter Laslett ed., student ed. 1988) (3d ed. 1698).

${ }^{70}$ See Kloppenburg \& Kleinman, supre note 23, at 189 (remarking on delay inherent in identifying value of plant accessions).

${ }^{1}$ Id. (quoting PIONEER HI-BRED INT'L, INC., CONSERVATION AND UTHIZATION OF EXOTIC GERMPLASM TO IMPROVE VARIETTES 47 (1984)).

${ }^{72}$ See ROBERT NOZICK, ANARCHY, STATE, AND UTOPIA 175 (1974) (discussing Locke's labor theory of property in context of entitlement theory). 
countries.

Second, the fact that a plant genetic resource is of unknown utility does not mean its value is so minimal that it should be appropriated freely. Ignorance of an item's value at a specific moment in time provides no justification for appropriating it when its value later becomes manifest.

Third, Locke's labor theory of property does not support the developed countries' reasoning because plant genetic resources from developing countries are not simple products of nature. Generations have expended labor in improving these plant genetic resources. $^{73}$ Locke's theory does not preclude proprietary rights to these resources because there is no minimum quantum of labor required to acquire proprietary rights. ${ }^{74}$ Domesticated plant varieties frequently vary dramatically in form from their wild or weedy relations. ${ }^{75}$ As one scholar notes, "the total genetic change achieved by farmers over the millennia was far greater than that achieved by the last hundred or two years of the more systematic science-based effort."76

Developed countries contend that the labor expended in preserving and nurturing plant genetic resources by developing countries does not complete the development of these resources. In their dayto-day agricultural activities, contemporary developing country farmers constantly produce and refine the genetic diversity that is the modern plant breeders' raw material. ${ }^{77}$ The germplasm of

${ }^{73}$ See BUSCH ET AL., supra note 2, at 58-59 (discussing role of farmers in plant selection).

74 Locke's theory is inconclusive when applied to plant genetic resources. The theory advocates an entitlement to property; it does not rationalize entitlement to property rights. To be entitled to something presupposes that all evidence weighed, an individual has a better claim than the rest of the world, and hence, proprietary rights. See STEPHEN R. MUNZER, A THEORY OF PROPERTY 260 (1990) (arguing absence of competing moral claim is necessary condition of laborer's property rights). Locke's theory only indicates that the breeders of elite plants may be more deserving of rights than developing countries. It does not demonstrate that developing countries do not deserve property rights on some other basis, such as group labor, ancestral trust or cultural property.

${ }^{75}$ See generally George C. Coggins \& Anne F. Harris, The Greening of American Law?: The Recent Evolution of Federal Law for Preserving Floral Diversity, 27 NAT. REsounCEs J. 247 (1987) (arguing for protection of not only cultivated plants but also uncultivated counterparts and habitat).

${ }^{76}$ NoRman W. SIMMONDS, PRnNCIPLes of Crop IMPRovemant 11 (1979).

7 See KeYSTONE CENTER, OSLO SESSION, supra note 21, at 13 (emphasizing importance of Farmers' Rights); KEYSTONE CENTER, MADRAS SESSION, supra note 8, at 9 (acknowledging farmers' contributions in concept of Farmers' Rights). 
developing countries' domesticated varieties is not a gift of nature. Instead, it is the product of millions of hours of human labor. Notwithstanding their contributions, scientists are not the sole producers of the utility embodied in commercial elite varieties. In recognition of this concept, the Madras Session of the Keystone Center noted that farmers' efforts can aptly be described as an "informal innovation system."78

The developed countries' arguments rely on a Eurocentric, individualistic understanding of property. ${ }^{79}$ This concept of property ignores the collective labor of generations. Arguably, the developed countries' concept rests on the assumption that plant genetic resources have no value until individuals in industrial countries incorporate their intellect into it. This Eurocentrism is monocultural and disrespectful of other cultural perceptions of property. Furthermore, this attitude focuses less on the purported interests of mankind than on the interests of maintaining Western hegemony in the control and utilization of plant genetic resources. Such a position relies on the belief that European creative genius recognized the greatness of developing country plant genetic resources and bestowed upon these resources the exalted status of "property," in contrast to their lowly former status as a common heritage. ${ }^{80}$ Applying a Eurocentric concept of property to plant genetic resources implies that until plant genetic resources achieve the status of property, these resources remain free for all.

Another argument advanced by the developed countries against commoditization is that raw plant genetic resources cannot be priced. Developed countries assert that until the raw genetic resource is priced, it is of unknown quantity and value. ${ }^{81}$

Admittedly, the pricing of raw plant genetic resources presents difficulties because the value of these resources is often latent. Consequently, the value of wild germplasm may not be discerned

${ }^{78}$ KeYstone CenTER, MAdras Session, supra note 8, at 7.

79 See generally Wendy J. Gordon, A Property Right in Self-Expression: Equality and Individualism in the Natural Law of Intellectual Property, 102 YALE L.J. 1533, 1641-44 (1993) (introducing natural rights approach to intellectual property).

${ }^{\circ}$ Cf. Coombe, supre note 38, at 257 (discussing transformation of "ethnographic specimens" of tribal works into "art" by European recognition of their greatness).

s1 See Koppenburg \& Kleinman, supre note 23, at 188 (commenting on purported distinction between utility of plant genetic resources and price placed on such utility). 
for many years. ${ }^{82}$ Focusing on the inability to price the wild germplasm permits the value of the whole to mask the value of the part. This inability does not vindicate the failure to assign value to an item which is conceded and appreciated as having some utility.

This pricing argument should not be used to preclude protection of other forms of intellectual property. Pricing of the use of a new song protected by copyright is ordinarily difficult. What is beautiful music to one man might be a dreadful cacophony to another. Yet, a minute number of notes and chords may receive copyright protection, allowing a new song to enter the market and subsequently be priced. Under this concept of intellectual property, then, one could argue that the price of an object is neither a necessary nor sufficient condition for protection. Why should pricing be relevant when it comes to raw plant genetic resources? One can trace the answer to this question to Eurocentrism, which refuses to recognize an object as property unless it fits neatly into certain conventional categories.

A final argument against commoditization of raw plant genetic resources is that collection of germplasm does not result in any deprivation to the source country. When sampling a plant population, collectors acquire only a few pounds of seed or plant matter, leaving the vast bulk of material untouched. Thus, it is asserted, unlike the extraction of other resources such as oil and minerals, the extraction of plant genetic resources results in no significant depletion of the resource itself.

On its face, this argument is air-tight. Its weakness lies in its failure to recognize that in extractions involving minerals, timber and allied resources, value is appropriated in direct proportion to the volume of the resource extracted. With plant genetic resources, however, the value of the whole is present in even minimal amounts. By supplying plant genetic resources as a free good without an exchange value, the donor country does not lose the genetic information but does lose the opportunity to receive a

82 For example, a collection of wild sugar beet was conducted in 1925 and 1935 in order to obtain plants resistant to leaf spot disease. It remained unused until 1976 when it was discovered that several accessions in the collection exhibited immunity to Rhyzomania, a devastating root disease. CONSULTATIVE GrouP ON INTERNATIONAL AGRICULTURAL RESEARCH, CGIAR FACT SHEET 61 (1992). 
reciprocal economic return for its contribution. Furthermore, the aggregate amount of a specific plant genetic resource possessed by a country is not the issue; rather, the issue is the distinct genetic information extracted from a country without compensation.

Arguments against commoditization raised by developed countries misrepresent the facts. The developing countries do not allege an infringement of ideas gained from the study of germplasm, but rather the taking of the germplasm and its genetic information. Without plant genetic resources from developing countries, developed countries could not have produced improved varieties. Although skills and efforts employed by a developed country may modify plant genetic resources and enhance their value, such "improvements" do not negate a taking of what belongs to the developing countries.

The genetic information embodied in the plant genetic resources is not fungible; it endures. Denying proprietary status to plant genetic resources is tantamount to treating these resources as fungible commodities. "Property that is merely fungible does not receive any special protection." ${ }^{83}$ Consequently, developing countries should secure compensation and share the profits from research and products emanating from their plant genetic resources. Developing countries should follow this course not only because their resources provide raw materials for new plant products, but also because biological materials and science have developed into businesses. Accordingly, their results no longer pass freely to all scientists. ${ }^{84}$ The stampede to patent improved plant varieties demonstrates this commercialization. ${ }^{85}$ No justification warrants the exclusion of developing countries from participating in the profits generated by use of their plant genetic resources.

The continued failure to commoditize plant genetic resources while categorizing them as part of a common heritage of mankind disguises the reality that international law reflects the geopolitical balance of power. International law represents the triumph of a Eurocentric individualistic concept of property, which ignores

\footnotetext{
w John Moustakas, Note, Group Rights in Cultural Property: Justifying Strict Inalienability, 74 CORNELL L. REV. 1179, 1190 (1989). F1.

Matricia Orwen, The Invasion of the Gene Snatchers, TORONTO STAR, May 8, 1994, at Id.
} 
collective labor's role in the acquisition of property, over a grouporiented African concept of property rights. This geopolitical balance drastically limits the options of developing countries and places them in a weak position to fight uncompensated extraction of their plant genetic resources.

The Prime Minister of Malaysia's statement at the 1992 Earth Summit in Rio de Janeiro emotionally depicted this position:

The poor countries have been told to preserve their forests and other genetic resources on the off-chance that at some future date something is discovered which might prove useful to humanity. ... We are also told that the rich will not agree to compensate the poor for their sacrifices. The rich argue that the diversity of genes stored and safeguarded by the poor are of no value until the rich through their superior intelligence, release the potential within. It is then an intellectual property and must be copyrighted and protected. ... The poor are not asking for charity. When the rich chopped down their own forests ... and scoured the world for cheap resources, the poor said nothing. Indeed, they paid for the development of the rich. Now, the rich claim a right to regulate the development of the poor countries. And yet any suggestion that the rich compensate the poor adequately is regarded as outrageous. As colonies, we were exploited. Now, as independent nations, we are to be equally exploited. ${ }^{86}$

Indian farmers have expressed similar sentiments:

if the hard-earned income of the people or the natural resources of any nation or region [is] ... plundered ... . [and] the goods produced by them are paid at arbitrarily determined prices while the goods bought by them are sold at high prices ... in order

Report of the United Nations Conference on Environment and Development, at 230, 231, 233, U.N. Doc. ACONF.151/26/Rev.1 (vol. V) (1993) [hereinafter UNCED Report]. 
to carry this process of economic exploitation to its logical conclusion ... then these are the indices of slavery of that nation, region or people. ${ }^{87}$

Vandana Shiva laments this state of affairs:

Some people's germplasm becomes a finished commodity, a "product," [and] other people's germplasm becomes a mere "raw" material for that product. The manufacture of the "product" in corporate labs is counted as production. The reproduction of the "raw" material by nature and Third World farmers is mere conservation. The "value added" in one domain is built on the "value robbed" in the other domain. Biotechnology development thus translates into biodiversity erosion and poverty creation. ${ }^{88}$

The issue of which plant genetic resources should be the subject matter of ownership and which resources should be freely accessible requires resolution. Before suggesting a framework for resolving this issue, it is necessary to examine the extent to which international efforts recommended at the Rio De Janeiro Earth Summit in 1992 effectively address it.

\section{AGENDA 21 AND THE BIODIVERSITY CONVENTION}

The 1992 Rio Earth summit produced three documents in addition to the Biodiversity Convention and the United Nations Framework Convention on Climate Change. ${ }^{89}$ These documents were: (1) Agenda 21, an 800-page collection of recommendations

\footnotetext{
97 Vandana Shina, The Violence of the Green Revolution 186-87 (1991) (quoting resolution adopted at All Sikh Convention in April 1986) (citation omitted).

${ }^{83}$ Id. at 254.

The objectives of the Biodiversity Convention are inter alia, the "conservation of biological diversity, the sustainable use of its components and the fair and equitable sharing of the benefits arising out of the utilization of genetic resources, including by appropriate access to genetic resources and by appropriate transfer of relevant technologies." Convention on Biological Diversity, June 5, 1992, art. 1, 31 1.L.M. 822, 823 (emphasis added) [hereinafter Biodiversity Convention].
} 
that nations should act upon to move towards sustainable development; (2) The Rio Declaration, a statement of twenty-seven basic principles for environmentally sound development; and (3) a statement of "forest principles" intended as a starting point for the negotiation of an international agreement on forest protection..$^{90}$ This discussion will focus on provisions pertinent to ownership and access to plant genetic resources in these documents.

Agenda 21 and the Biodiversity Convention furnish a framework for regulation of plant genetic resources. These documents espouse a principle vital to ownership of plant genetic resources-the sovereign right of states over genetic resources found within their borders. Under Agenda 21, states "have the sovereign right to exploit their own biological resources pursuant to their environmental policies". ${ }^{\prime 1}$ Further, states have the duty to conserve diversity and promote sustainable utilization of biological resources. ${ }^{82}$

Under the Biodiversity Convention, not only do states have sovereign rights over their natural resources, but also "the authority to determine access to genetic resources rests with the national governments and is subject to national legislation. ${ }^{\text {"93 }}$ To balance the interests of the scientific community and the source state, the Biodiversity Convention commands states to "take legislative, administrative or policy measures . . . for sharing in a fair and equitable way the results of research and development and the benefits arising from the commercial ... utilization of genetic resources with the [source of] such resources. ${ }^{n 94}$

These provisions exhibit a reciprocity theory that countries which sacrifice to conserve natural species, as well as countries whose industries transform raw germplasm into useful products, should be entitled to receive a portion of the profits from the sale of these

${ }^{\infty}$ Edith B. Weiss, Introductory Note to United Nations Conference on Environment and Development, 31 I.L.M. 814 (1992); AGENDA 21 AND THE UNCED PROCEEDINGS passim (Nicholas A. Robinson ed., 1993).

91 Report of the United Nations Conference on Environment and Development, at 103, U.N. Doc. AVCONF.151/26 (vol. II) (1992) [hereinafter Agenda 21].

Biodiversity Convention, supra note 89, arts. 6, 8, 10, at 824 .

${ }^{0}$ Biodiversity Convention, supra note 89, art. 15, at 828 .

Id. 
products. ${ }^{95}$ The Convention thus disavows the notion that plant genetic resources are a common heritage of mankind. The Convention, however, gives states the right and responsibility of governing their genetic resources in their relations with other states and their inhabitants instead of recognizing the proprietary rights in the genetic resources of a state. ${ }^{96}$

Neither Agenda 21 nor the Biodiversity Convention explicitly address the ownership of plant genetic resources. Instead, the documents emphasize national obligations to conserve plant genetic resources. In addition, the documents provide for access to plant genetic resources and products thereof.

Under the Biodiversity Convention, access to, and transfer of, technology (including biotechnology) to developing countries is to be provided under "fair and most favorable terms." mutual agreement exists, this access and transfer may be on "concessional and preferential terms." In cases involving patented technology and other intellectual property, "such access and transfer shall be provided on terms which recognize and are consistent with the adequate and effective protection of intellectual property rights ... [ [and] which are to be supportive of, and not to run counter to the [convention's] objectives. ${ }^{\text {"99 }}$

\% In the spirit of compensation, recent examples show corporations recognixing entitlements in natural plant genetic resources. The pharmaceutical giant Merck has implicitly acknowledged an obligation to compensate for the use of raw plant germplasm in a much-publicized venture with the government of Costa Rica. Leslie Roberts, Chemical Prospecting: Hope for Vanishing Ecosystems?, 256 SCIENCE 1142, 1142 (1992). Merck agreed to pay Costa Rica's National Institute of Biodiversity (INBio) an initial fee of $\$ 1$ million to undertake high-tech chemical prospecting in Costa Rica's rain forests, and will provide INBio a percentage of the profits on any drugs derived from plants or microorganisms provided by the Costa Rican researchers. Id. at 1143. The American Cancer Institute and Smith-Kline Beecham have made similar arrangements in Cameroon and Ghana, respectively. Tom Reynolds, Drug Firms, Countries Hope to Cash in on Natural Praducts, 84 J. NaT'L Cancer INST. 1147, 1148 (1992). The National Science Foundation, the Agency for International Development, and the National Institutes of Health, have begun a grant program designed to foster conservation and compensation for plant genetic resources. Constance Holden, Combining Economics with Biodiversity, 258 SCLENCE 551, 551 (1992).

* Frederick Hendrickx et al., Convention on Biological Diversity-Access to Genetic Resources: A Legal Analysis, 23 ENvTL. POL'Y \& L. 250, 256 (1993).

${ }^{17}$ Biodiversity Convention, supre note 89, art. 16, at 829.

${ }^{\infty}$ Id.

${ }^{\infty}$ Id. 
Developed countries, specifically the United States, have objected to the access provisions of the Biodiversity Convention. ${ }^{100}$ The United States asserts that the provisions are unacceptable to the extent they imply that patents are only to be respected when they do not prevent universal distribution of patented products. ${ }^{101}$ The United States argues that "fair and equitable" sharing is equivocal. ${ }^{102}$ If a large number of countries found American patent laws restrictive, they would probably hold these laws to be internationally unfair and invalid. Accordingly, the United States argues that the Convention's language would permit countries to disregard patent rights or to claim a share of the patent benefits derived from products based upon their natural resources, even in the absence of any royalty contract. ${ }^{103}$

Despite this interpretation, the U.S. disagrees only when the Convention's text shifts from protecting biodiversity to actual regulation of biotechnological results. ${ }^{104}$ When compensatory entitlement is claimed for in situ $u^{105}$ raw genetic material, the United States has no objection, ${ }^{106}$ in effect conceding that the common heritage concept is an imperfect concept for plant genetic resources. ${ }^{107}$

During the 1992 Rio Earth Summit in Brazil, a bid by developing countries to amend the Biodiversity Convention to address access

${ }^{100}$ Stone, supra note 26, at 1624.

101 The Earth Conference: Biodivisive, ECONOMIST, June 13, 1992, at 93.

102 Margulies, supra note 1, at 337.

${ }^{103}$ The Earth Conference: Biodivisive, supra note 101, at 93.

${ }^{104}$ Margulies, supra note 1, at 339.

${ }^{106}$ In situ genetic resources are those plant genetic resources found in their natural habitat. In contrast, ex situ genetic resources are those removed from their natural habitat and stored as seeds, tissue or pollen in field gene banks, or in other live collections.

${ }^{106}$ According to State Department officials, the United States agrees with the principle that underdeveloped nations should be compensated for use of their genetic resources. Jane Perlez, Environmentalists Accuse U.S. of Trying to Weaken Global Theaty, N.Y. TmMas, May 19,1992 , at C4.

${ }^{107}$ Cf. Malcolm Gillis, Economics, Ecology, and Ethics: Mending the Broken Circle for Tropical Forests, in ECOLOCY, Economics, ETHCS: ThE BROKGEN CIRCLE 155, 175 (F. Herbert Bormann and Stephen R. Kellert eds., 1991) (offering joint financing and policy reforms as solutions to freerider problem); Kloppenburg \& Kleinman, supra note 23, at 192 (stating common heritage doctrine may be detrimental). 
to ex situ germplasm collections and farmers' rights failed. ${ }^{108}$ In light of this failure, the Biodiversity Convention avoids addressing the legal status of ex situ plant genetic resources. Consequently, Genetic Resources Action International (GRAIN) has noted that "the Biodiversity Convention is a 'small step forward in conservation' but a large step backward for Third World control over the valuable international germplasm collection run by the Consultative Group on International Agricultural Research (CGIAR).'

Despite criticism from developing countries, Agenda 21 goes further than the Biodiversity Convention in protecting in situ plant genetic resources to the extent that it explicitly recognizes farmers' rights and the role of indigenous people as "hav[ing] an historical relationship with their lands .....$^{n 10}$ Accordingly, states are urged to "adopt ... appropriate policies ... that will protect indigenous intellectual and cultural property."111 Agenda 21 recommends a "farmer-centred approach" to sustainable development. ${ }^{112}$

Although it recognizes farmers' rights, Agenda 21 does not acknowledge proprietary rights in plant genetic resources themselves. As the Prime Minister of Ethiopia has noted, the present Convention falls short of comprehensively covering issues related to use, ownership, funding and the transfer of technology developed from biological resources. ${ }^{113}$ Echoing similar sentiments, a report by GRAIN has concluded that the Biodiversity Convention is extremely weak and even counter-productive in two respects. ${ }^{114}$ First, the door is opened for the patenting of genetic materials. ${ }^{115}$ Second, the Convention excludes a crucial part of the world's

${ }^{108}$ Exclusion of CGIAR Germplasm Banks From Convention on Biological Diversity Raises Ire of Non-Governmental Organizations, DiversiTY, vol. 8, no. 3, at 5, 5 (1992) (discussing failed attempt) [hereinafter CGIAR Exclusion].

${ }^{100}$ Id. (citation omitted).

${ }^{110}$ Agenda 21, supra note 91 (vol. III), at 16.

"111 Id. at 18.

${ }^{112}$ Id. at 39 .

118 UNCED Report, supra note 86, at 147.

114 CGLAR Exclusion, supra note 108, at 5.

${ }^{115}$ Id. 
biodiversity, ex situ plant genetic resources held in gene-banks. ${ }^{116}$ This exclusion has raised questions regarding the legal status of $e x$ situ plant genetic resources.

\section{Gene Banks and Plant Genetic Resources}

One scholar estimates that over 2.5 million crop accessions are held in gene banks throughout the world. ${ }^{11}$ Most of these accessions are wild and weedy "ancestral" species or "primitive" cultivars of plant varieties; the source for modern elite commercial plant varieties. Ownership of plant genetic resources that have been collected in one country and preserved in the gene banks of another, and possibly improved in yet another country presents a legal problem. ${ }^{118}$ Concern over the legal status of these resources results from reports that certain countries or firms restrict the flow of ex situ plant genetic resources for political and commercial reasons. 119

At issue are the plant genetic resources in gene banks controlled by the Consultative Group on International Agricultural Research $(\mathrm{CGIAR})^{120}$ and IBPGR. Most of the collections controlled by the IBPGR are in developed countries. Consequently, these countries, which have limited diversity in plant genetic resources, have accumulated large quantities of germplasm equivalent to those found in developing countries. With respect to potato, wheat, and food legumes, for example, developed countries have more germplasm in stored accessions than developing countries have in a

${ }^{116}$ See Biodiversity Convention, supra note 89, art. 15, at 828 (defining countries which provide "genetic resources" so as to exclude genebanks). Genetic resources stored in gene banks or kept under ex situ conditions in a country and obtained before the Convention went into effect are excluded from regulation and subject to treatment as the common heritage of mankind. Hendrickx et al., supra note 96 , at 251.

117 See DoNald L. PLUNCKeTt ET AL., GeNE BANRS AND THE WORLD's FoOd 110 (1987) (including over 1.2 million accessions of cereals; 369,000 accessions of food legumes; 215,000 accessions of forage legumes and grasses; 137,000 accessions of vegetables; and 74,000 clones of root crops).

118 Id. at 4.

119 JUMA, supra note 4, at 200-01.

${ }^{120}$ CGIAR is an informal association of forty public and private sector donors supporting a network of 16 international agricultural research centers, including IBPGR. CONSULTATIVE Group ON INTERNATIONAL AGRICULTURAL RESEARCH, CGIAR FACT SHEET 9, at 1 (1992) [hereinafter FACT SHEET 9]. 
natural diversity of these crops. ${ }^{121}$ The wealthiest countries, which contain the smallest and least interesting biotas, thus preside over the largest collection of germplasm. Thus, the centers of diversity have shifted from the natural systems of primitive cultivars to gene banks. This situation attracts concern because no specific legislation confers proprietary rights over the genetic resources in these gene banks. ${ }^{122}$

Presently, the resources in the gene banks are recognized as part of the common heritage of mankind. As such, they are freely accessible to all scientific researchers and plant breeders. The ownership of these resources, however, remains unclear. ${ }^{129}$ To discern the legal status of these resources, one must resort to the constitutive headquarter agreements establishing each of the CGIAR gene banks.

The organization of CGIAR centers varies. ${ }^{124}$ While some centers operate on a private contract basis, others function according to more comprehensive arrangements involving international organizations and formal international law. The constitutive instruments may be interpreted to give the host country rights to a center's germplasm collection if the center is officially closed, moved or shut down due to hostilities or natural disaster. ${ }^{125} \mathrm{~A}$ survey by IBPGR indicates that most centers hold their genetic collections as part of the centers' assets and would be treated as such on dissolution. ${ }^{126}$ Therefore, the host governments own the collections upon dissolution and could dispose of them without restriction. ${ }^{127}$

121 See, e.g., Donald L. Plunckett et al., Crop Germplasm Conservation and Developing Countries, 220 SCIENCE 163, 165 (1983) (discussing disparity of germplasm resources between developed and developing countries).

122 See generally, David R. Downes, New Diplomacy for the Biodiversity Trade: Biodiversity, Biotechnology, and Intellectual Property in the Convention on Biological Diversity, 4 TOURO J. TRANSNAT'L L. 1 (1993) (discussing uncertain treatment of proprietary rights over seeds held in gene banks before Convention on Biological Diversity).

${ }^{123}$ Wolfgang Siebeck \& John Barton, The Implications of Applying the Legal Concept of Trust to Germplasm Collections at CGIAR Research Centers, DIVERSITY, vol. 8, no. 3, at 29, 29 (1992).

is See id. at 31 (outlining various legal arrangements under which centers operate).

${ }^{125}$ Id. at 29.

${ }^{128} I d$.

${ }^{127}$ Id. at 29-30. 
Because the constitutive documents creating the gene banks are legal instruments, unilateral revocation by founders or sponsors of the centers cannot transpire. Dissolution of a center can occur only by a decision of its members. ${ }^{128}$ Members of these centers includes individuals, non-governmental organizations, and a few donor-governments who control the collections. In most cases, countries from which the specimens in the collections originate do not have membership status. The 1988 CGIAR Technical Advisory Committee report suggested that ownership of genebanks held by the CGIAR centers is influenced partly by agreements with host countries that vary among centers. ${ }^{129}$ This diversity has several significant ramifications.

First, although constitutive headquarter agreements permit the host state to revoke these agreements, the act of revocation does not affect the existence of the gene bank center. Rather, it affects its right to reside in the host country. In addition to being ineffective, revocation would violate the international legal concept of pacta sunt servanda. ${ }^{130}$

Second, the CGIAR centers are "international only in a loose sense because of their international support and objectives, and their relative autonomy within their host countries. ${ }^{\text {131 }}$ They are not international in the strict sense because they are not created by formal treaty among states or other international legal persons, and states or international persons do not direct their activities. The legal status of these centers, and hence their collections of plant genetic resources, is sui generis, neither national nor international.

123 Siebeck \& Barton, supra note 123, at 31.

120 Id.

${ }^{130}$ See H. LAUTERPACHT, THE FUNCTION OF LAW DN THE INTERNATIONAL COMMUNITY 41883 (1933) (explaining principle of pacta sunt servanda); see also HANS KELSEN, THE PURE THEORY OF LAw (1934), reprinted in LOUIS HENKRN ET AL., INTERNATIONAL LAW: CASES AND MATERIAIs 20 (1993) (discussing pacta sunt servanda as ability of states to regulate mutual relations by treaty); accond Dotse A. Tsikata, Sovereign Borrowers, Foreign Creditors and the Resolution of Sovereign Insolvency: A Legal Appraisal of Contemporary Practice 139 (1993) (unpublished SJD thesis, University of Toronto) (on file with author).

${ }^{231}$ Siebeck \& Barton, supra note 123, at 31 (citing FOOD AND AGRICULTURAL ORGANIzAtion [FAO], legal Status of Base and active Collections of Plant Genetic RESOURCES, FAO, Doc. CPGR/87/6 (1986)). 
Third, the legal status of the IBPGR is questionable. ${ }^{132}$ While appreciating the scientific contributions of IBPGR, developing countries have questioned its lack of juridical personality. ${ }^{139}$ In the creation and practices of these organizations, the control of crops and conservation has passed from member governments of the United Nations to a loose group of governments, scientists and private foundations from developed countries. ${ }^{134}$ In this respect, the IBPGR exists outside any form of international control. This lack of international control has facilitated the transfer of plant genetic resource from their centers of origin to the gene banks of developed countries. ${ }^{135}$ This situation has illuminated the absence of clear mechanisms, other than moral suasion, for enforcing the free exchange of plant genetic resources in the gene banks. ${ }^{136}$

Pursuant to the developing countries' concerns about IBPGR's status, representatives of five governments signed an agreement establishing an International Plant Genetic Resource Institute (IPGRI) to replace IBPGR on October 9, 1991. ${ }^{137}$ This agreement provides IPGRI with international status. ${ }^{138}$ One of its objectives is "to assist countries, particularly developing nations, to assess and meet their needs for plant genetic resources conservation, and to strengthen links with users ${ }^{\text {n139 }}$ of these resources. The new organization adopts the principle that plant genetic resources are a common heritage of mankind and are freely accessible in the public domain. ${ }^{140}$

Notwithstanding the creation of this new organization, the key question at the international level is whether the ownership of ex situ plant genetic resources from developing countries should

L29 KLOPPENBURG, supra note 22, at 172.

${ }^{130}$ Id. at 172-73.

194 JUMA, supra note 4, at 207 n.43 (asserting that creation of IBPGR has meant transfer of control from United Nations member governments to ill-defined group of governments, scientists, and private foundations).

283 Id.

136 KLOPPENBURG, supra note 22, at 172.

157 See FACT SHEET 9, supra note 120, at 1 (outlining establishment and objectives of IPGRI).

${ }^{238}$ See id. (observing that IPGRI operations dependent upon ratification of Headquarters Agreement by Italian Parliament).

139 Id. at 2.

${ }^{140}$ Kloppenburg \& Kleinman, supra note 23, at 173. 
continue to be viewed as a common heritage of mankind with free access to researchers and plant breeders. In answering this question, one must consider three categories of plant genetic resources: (1) uncollected wild and natural plant genetic resources, that is, in situ plant genetic resources; (2) wild and natural genetic plant resources that may be stored in established gene banks in the future; and (3) collected material already stored in established gene banks, that is, ex situ plant genetic resources.

\section{OWNERSHIP OF IN SITU UNCOLLECTED WIID AND Natural Plant Genetic Resources}

Contemporary international law characterizes plant genetic resources as a common heritage of mankind. This characterization insufficiently resolves the ownership of these resources. The concept of common heritage has no legal application to plant genetic resources found within the borders of a sovereign state and should be abolished. The concept of national sovereignty provides a better solution to the problem of ownership of plant genetic resources.

As a precept of public international law, nation-states have jurisdiction over all persons and things found within their territorial boundaries. ${ }^{141}$ Accordingly, nation-states have the prerogative to prevent all persons from interfering with things found within their borders. ${ }^{142}$ Moreover, sovereign states have the right to defend their territorial integrity and resources against external interference. ${ }^{143}$

Agenda 21 and the Biodiversity Convention recognize these rights. ${ }^{144}$ Such recognition bolsters the argument that the concept of a common heritage of mankind has no legal foundation for application to plant genetic resources. As Li Peng, the Prime Minister of China, asserted, "each country enjoys sovereign rights

${ }^{141}$ See generally LOUIS HENKIN ET AL., INTERNATIONAL LAW: CASES AND MATERLALS 106186 (1993) (discussing bases of, and limits on, jurisdiction).

${ }^{112}$ Id.

${ }^{109}$ Id.

${ }^{14}$ Agenda 21, supre note 91 (vol. III), at 16; Biodiversity Convention, supra note 89, art. 15 , at 828 . 
over its natural resources and biological species. ${ }^{\text {n145 }}$

Developing countries support this argument. At the Earth Summit in Brazil, President Yoweri Kaguta Museveni of Uganda stated that:

I am pleased that a compromise has emerged on the biological diversity issue. I had a major problem because I heard that some people were trying to say that forests in Uganda belong to the whole world; I was not going to accept that. I have heard that an agreement has been reached that the forests in Uganda belong to Uganda and that if someone wants to come and use those forests, he must get a licence from us and we will share the profits. That is a great relief to me, because I was going to oppose this - there was no doubt. ${ }^{146}$

President Ali Hassan Mwinyi of Tanzania espoused similar sentiments:

Most of us in developing countries find it difficult to accept the notion that biodiversity should be considered the common heritage of mankind while the flow of biological products from the industrial countries is patented, expensive and considered the private property of the firms that produce them. This asymmetry reflects the inequality of opportunity and is unjust. ${ }^{147}$

At the same meeting, President Daniel Arap Moi of Kenya expressed his concerns:

We also believe in the right of nations to exploit and trade in a sustainable and responsible manner the natural resources found within their legal bound-

${ }^{246}$ UNCED Report, supra note 86, at 36.

106 Id. at 24.

${ }^{147}$ Id. at 189. 
aries. In the same vein, we feel that the natural resources located outside the legal boundaries of any country, including those located in the outer space and in the high seas, are to be treated as mankind's common heritage. ${ }^{148}$

This Article suggests that after abrogating the concept of common heritage of mankind and taking control of its genetic resources, individual states can legislate the terms and conditions of access to their genetic resources. The Biodiversity Convention provides for such action, permitting states "to take legislative ... measures, ${ }^{\text {149 }}$ provided that remuneration arrangements reflect "a fair and equitable ${ }^{\text {n150 }}$ sharing of the results of research and royalties arising from any patented invention. It is unclear what would constitute "fair and equitable" sharing in this context. ${ }^{151}$ Developing countries should enact a "Genetic Resources Access and Remuneration Act" to abolish the concept of common heritage of mankind with respect to plant genetic resources under their national sovereignty.

In abjuring the concept of common heritage, one must note that any stringent restrictions on collection and research of germplasm might impede the utilization of wild plant genetic resources. This delay would have serious ramifications for biotechnology research because few developing countries have the requisite scientific resources and fiscal wherewithal to undertake such research unaided. ${ }^{162}$ Moreover, even an agreement on access to, and remuneration for, plant genetic resources may not, in practice, work in favor of developing countries. Such agreements cannot ensure equitable outcomes when the parties have unequal bargaining power due to transaction-specific failures, such as when a developing country is overborne by economic pressures or lacks

140 Id. at 101.

140 Biodiversity Convention, supra note 89 , art. 15 , at 828 .

${ }^{150} I d$.

151 Margulies, supra note 1, at 337.

${ }^{162}$ See Otto H. Frankel, Genetic Resources: Evolutionary and Social Responsibilities, in SeEds AND SOVErtignty: THE USE aNd CONTROL OP PLANT GENETtC REsources 19, 39 (Jack R. Kloppenburg Jr. ed, 1988) (noting dearth of qualified scientists in developing countries). 
sufficient technical information to assess its own interest.

A moral code of conduct for collectors of plant accessions should also be considered. The Keystone Madras Session noted that "germplasm collection ... should be carried out under an acceptable ethical code and include procedures such as the explicit advanced clearance by the concerned country and sharing the collected material and information about the material with the host country. ${ }^{\text {163 }}$ Such a code would prohibit unscrupulous practices such as one documented by the Rural Advancement Foundation International (RAFI), in which plant collector Clive Francis of Australia "violated his contract by pocketing lucerne (alfalfa) seed he was sent to study in North Africa, and returning to Australia, now claims the seeds are 'worth millions' to [that] country's livestock industry. 154

What do developing countries stand to gain from the abolition of the concept of a common heritage? First, abolishing the concept commoditizes plant genetic resources and thus treats them the same as the elite commercial varieties under intellectual property laws. This equality of treatment achieves equity in the categorization of plant genetic resources of developed and developing countries.

Second, abolition of the concept of common heritage is more feasible than de-commoditization of the elite commercial varieties of the developed countries. Abolition of the common heritage concept requires only legislative action on the part of the governments of developing countries. This action acknowledges the reality that multinational plant breeding firms will not readily accept the de-commoditization of the elite commercial varieties, which they consider corporate assets.

Third, eradication of the common heritage concept would amount to a recognition of proprietary rights and the creation of a compensatory mechanism for plant genetic material coming from developing countries. Such achievements would rectify a substantial imbalance in economic power between the advanced industrial

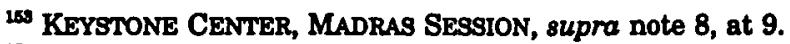

ist The Benefits of Biodiversity: 100+ Examples of the South's Contribution to the North's Development through Rural Communities, RAFI CoMmunique (Rural Advancement Found. Int', Ottawa, Ontario), at 2. 
nations and the developing countries. ${ }^{155}$ Recognizing that most developing countries that are rich in plant genetic resources are also relatively poor in biotechnology, commoditization of plant genetic resources will enrich these states by permitting exportation of these resources to locations where they are valued according to free market principles. ${ }^{158}$ The nation or its citizens will receive returns from the export of plant genetic resources. In this regard, Kloppenburg and Kleinman note that it is better to receive revenue from exports than never to receive any money at all. ${ }^{157}$

Fourth, declaring plant genetic resources as the property of the state in which they are located produces a positive impact on biodiversity preservation. ${ }^{168}$ National governments could entertain claims by their farmers, finders and corporations, use all proceeds from licenses for the collective benefit of their citizens, or set up a large system of village-level landrace custodians whose purpose would be to continue to grow a limited sample of endangered landraces native to the region. ${ }^{159}$

\section{OWNERSHIP OF WILD AND NATURAL PLANT GENETIC} Resources to be STORED IN GENE BANKS IN THE FUTURE

This Article has asserted that abrogation of the concept of common heritage will make plant genetic resources national property. National law pertaining to transfer, alienation, and disposition of property should be applicable to this process. Based on this assumption, access to and utilization of plant genetic resources should occur by contract between the state or its authorized agent and the acquiring party (gene-bank) or its authorized agent. The storage of genetic resources collected from the wild and natural species should also occur on a contractual

${ }^{165}$ See Kloppenburg \& Kleinman, supra note 23, at 195 (suggesting additional solutions to "plant germplasm controversy").

${ }_{160}$ But cf. Coombe, supra note 38, at 261 (objecting to argument, in context of cultural objects, that price determines value).

${ }^{167}$ Kloppenburg \& Kleinman, supra note 23, at 195.

${ }^{168}$ See.Roger A. Sedjo, Property Rights and the Protection of Plant Genetic Resources, in SEeds AND SOVEREIGNTY: THE USE AND CONTROL OF PLANT GENETIC RESOURCES 293, 308 09 (Jack R. Kloppenburg Jr. ed., 1988) (discussing potential outcomes from such declaration).

${ }_{150}$ Miguel A. Altieri \& Laura C. Merrick, Acroecology and In Situ Conservation of Native Crop Diversity in the Third World, in BIodrversITY 316, 362 (Edward O. Wilson ed., 1988). 
basis between the same parties. Notwithstanding the foregoing, abolition of the concept of common heritage of mankind does not address the fundamental question of ownership of plant genetic resources currently stored in gene banks.

\section{OWNERSHIP OF PLANT GENETIC RESOURCES ALREADY STORED IN GENE BANKS}

Before considering solutions to the ownership question of plant genetic resources, it is important to discuss the view of CGIAR, which controls most of the gene banks. In 1989, CGIAR stated that its policy is "that collections assembled as a result of international collaboration should not become the property of a single nation, but should be held in trust for use of present and future generations of research workers in all countries throughout the world. ${ }^{160}$ Once a country has collaborated in the collection of the plant genetic resources, any exclusive ownership right to the collected material terminates. ${ }^{161}$ The materials are then held by the CGIAR centers in trust for all people. ${ }^{162}$

Siebeck and Barton hold a similar view, that base material (unimproved material) in gene banks should be held in trust regardless of who is the formal legal owner. ${ }^{163}$ This reflects an underlying notion of a common heritage of mankind. These advocates state that "the CGIAR centers, as trustees, are obligated to maintain the germplasm carefully and must ensure that it is widely available for plant breeding. ${ }^{\text {.164 }}$

In order to resolve the ownership of plant genetic resources presently stored in gene banks, this Article adopts Siebeck and Barton's position, minus the common heritage concept. CGIAR centers should hold germplasm collections in trust, not for the benefit of researchers, but for the benefit of the country in whose territory the germplasm was collected. Access to this genetic material should be subject to the payment of adequate compensation by the research community.

\footnotetext{
${ }^{160}$ Siebeck \& Barton, supra note 123, at 32.

${ }^{101}$ Id. at 31.

${ }^{100} I d$.

${ }^{260} I d$.

${ }^{104}$ Id. at 33-34.
} 
What would be the legal status of the germplasm currently stored in the gene banks? Annulment of the concept of common heritage implies that countries from which plant genetic resources were collected have not renounced their proprietary rights over the material; these countries have merely transferred possession of their plant germplasm to the CGIAR centers. Therefore, states should retain sovereign proprietary rights over the germplasm in gene banks. ${ }^{165}$

Implementation of this position would encounter three difficulties. First, it could create a situation in which developing countries become competing suppliers of plant genetic resources, compounding primary commodity problems already present in the contemporary international trade arena. ${ }^{166}$ Second, given the nature of the stored genetic material, the proposal requires isolation and determination of the country from which a particular germplasm originated. Currently, documentation does not exist for all germplasm stored in gene banks. ${ }^{167}$ Further, no uniform system indicates the origin of each sample, nor details of structural or chemical composition sufficient to correlate collected samples. ${ }^{168}$ Third, the proposal retroactively abolishes the concept of a common heritage. In practice, retroactivity meets with disfavor because it may raise legal difficulties in dealing with rights previously acquired under the common heritage concept.

\footnotetext{
${ }^{165}$ In this respect, scientists and researchers would gain access to these materials subject to agreement that any research results generated by use of the material so obtained shall be subject to compensatory and royalty provisions for the benefit of the country in whose territory the material was collected.

${ }^{168}$ Primary products, especially agricultural commodities, have recently been subjected to fluctuating prices and declining demand owing to competition from synthetic fibers. WORLD BANK, WORLD DEVELOPMENT REPORT - POVERTY 13 (1990). Even when the demand for agricultural produce is high, the supply has not been able to respond immediately as there is a time lag involved in the production of agricultural produce. Id.

${ }^{167}$ Cf. David Wood, Crop Germplasm: Common Heritage or Farmers Heritage?, in SEEDS AND SOVEREIGNTY: THE USE AND CONTROL OF PLANT GENETIC RESOURCES 275, 282 (Jack R. Kloppenburg Jr. ed., 1988) (suggesting necessary changes to current germplasm storage and documentation procedures).
}

${ }^{188}$ Id. at 282. 


\section{Vesting of Plant Genetic Property Rights: STATE, INDIVIDUAL OR ANOTHER ENTITY?}

One of the initial problems confronting commoditization of plant genetic resources is the determination of which entity qualifies for proprietary rights in natural, discovered, or protected plant species. Approximately three billion people in the world farm; perhaps property entitlements should reward their efforts in the collection, improvement, and conservation of these genetic resources. Indigenous peoples may also possess valid claims to property rights through their knowledge of the plant materials in their environments. The nation-state, by virtue of sovereignty, may also hold a legitimate stake in proprietary rights. The question of which competing entities should have the proprietary rights remains.

This question is important because the law of property, besides imposing duties, provides distributively for the individual or entity who holds property rights-every right has a holder and rights cannot exist without a right holder. ${ }^{169}$ Commoditization of rights in plant genetic resources affects the distribution and control of these resources. These proprietary rights reflect the way in which rights serve as norms for distribution between the right holder and the non-right holder. At the outset, two entities are candidates for the vesting of plant genetic property rights: nation-states and individuals. ${ }^{170}$ Various scholars throw their weight behind one or the other. This Article proposes a third possible candidate-the group or community.

Jack Kloppenburg and Daniel Kleinman support the idea that the nation-state is a viable entity in which to vest plant genetic property rights. ${ }^{171}$ They note that national sovereignty over plant genetic resources points to one inescapable conclusion: "[the third world countries] have a great deal to gain through international acceptance of the principle that plant genetic resources constitute

169 Carl WeLllMaN, A THEORY OF RJGHTS $189-195$ (1985).

${ }^{170}$ See Kloppenburg \& Kleinman, supra note 23, at 199 (supporting view that nation-state is appropriate entity in which to vest plant genetic resource property rights); but see Wilkes, supra note 6, at 84-85 (rejecting Kloppenburg and Kleinman's theory because it privatized longstanding public good).

${ }^{171}$ Kloppenburg \& Kleinman, supra note 23, at 194. 
a form of national property. ${ }^{\prime 72}$ The establishment of this principle would provide a framework through which developing countries would receive compensation for the appropriation and use of their plant genetic resources.

A nuisance inherent in using sovereignty as the basis for vesting plant genetic resources is the inefficiency and bureaucracy attendant to state ownership. Moreover, state ownership centralizes all plant resources and decisions about their use. Consequently, bureaucrats manage precious resources and provide access through bureaucratic allocations. ${ }^{173}$

A competing candidate for the vesting of proprietary rights in plant genetic resources is the individual. A Eurocentric conception arguably predicates property on free enterprise and individual ownership. Consequently, commoditization must necessarily vest in an individual and not in a nation-state. This individualism entails decentralization, delegating ownership of plant genetic resources to many individuals who have substantial (although not absolute) power to manage and control their use and disposition. Central to this perspective is the property concept of wide-scale small-share ownership where resources are widely owned in small amounts. ${ }^{174}$

This Article suggests the possibility of abandoning not only the notion of nation-state ownership, but also the concept of individual ownership of plant genetic resources. In so doing, it examines entities in African customary society that could be made "persons" under international law, and thereby vested with plant genetic property rights. Assuming these entities exist, what is their nature and are they appropriate owners of property rights in plant genetic resources? An analysis of customary African practices related to land lends insight into the nature of these groups and communities.

In customary African land law, the notion of individual ownership is alien. As a general rule, customary practice bases ownership of land on groups and communities as land-owning entities. An individual enjoys rights in land as a member of the land-owning

\footnotetext{
in Id.

${ }^{173}$ Joseph W. Singer \& Jack M. Beermann, The Sacial Origins of Property, 6 CAN. J.L. \& JURISPRUDENCE 217, 241 (1993).

174 Id. at 242.
} 
unit. $^{175}$ To perform its tasks, the group acts through an agent, namely the chief, the village head, or the clan leader. ${ }^{176}$ Customary practice regards the chief as the symbol of the residuary, reversionary, and ultimate ownership of all land held by the community. ${ }^{177}$ In this sense, the chief is a trustee. ${ }^{178}$

This Article proposes vesting proprietary rights to plant genetic resources in such customary groups and communities. This proposal, however, entails recognition that the concept of promoting the community's general welfare provides an important justification for holding cultural property inalienable. ${ }^{179}$ The necessity of inalienability stems primarily from future generations' inability to consent to transactions that threaten their existence as a group. The belief that commoditization and fungibility are inappropriate ways to treat constitutive elements of grouphood and are inimical to communal development bolsters the need for inalienability. ${ }^{180}$

Conceding that this concept of grouphood is pertinent to ownership of plant genetic resources, this Article does not endorse inalienability of plant genetic resources. Instead, it endorses commoditization and alienability of plant genetic resources as valuable objects of trade that contribute to the well-being of all peoples. If plant genetic resources are made inalienable, no reallocation of resources to more valuable applications would be possible. ${ }^{181}$ If one recognizes that the countries that are rich in plant genetic resources have no technological and fiscal wherewith-

\footnotetext{
${ }^{175}$ Max Gluckman, Property Rights and Status in African Traditional Law, in IDEAS AND PRocedURES IN AFRICAN CUSTOMARY LAW 252, 252 (Max Gluckman ed., 1969).

${ }^{176}$ A.N. Allott, Legal Personality in African Law, in IDEAS AND ProcedURES IN AFRICAN CUSTOMARY LAW 179, 191 (Max. Gluckman ed., 1969).

${ }^{177}$ Amodu Tijani v. Secretary, Southern Nigeria, 1921 App. Cas. 399, 404 (appeal taken from Nig.).

${ }^{178}$ The use of the word "trustee" in the African land holding differe from its ordinary English meaning. In English law, a trustee is the legal owner of the property and is bound to administer the trust property on behalf of the beneficiaries. See BLACK's LAW DICTIONARY 1684 (4th ed. 1951) (defining trustee). In customary African law, the chief was bound to control the land belonging to the group for the benefit of the members of the community. It is only in this respect that their position resembled that of a trustee. The headman had control but not ownership of the land. In this respect, his position was more like that of an agent. Tijani, 1921 App. Cas. at 404-05.

179 Moustakas, supra note 83, at 1185.

${ }^{180}$ Id. at 1210-1211.

${ }^{181}$ RICHARD A. POSNER, ECONOMIC ANALYSIS OF LAW \& 3.1, at 34 (4th ed. 1992).
} 
al to utilize the resources, then making resources inalienable is tantamount to hoarding a valuable resource to humanity's detriment.

What are the reasons for the vesting of plant genetic property rights in these group entities rather than in the individual or the nation-state? First, taking into account that traditional groups and communities have, over many generations, conserved and preserved the plant genetic resources, it follows that these groups deserve a proprietary reward for their conservation efforts. Furthermore, it is easier to vest such property rights in the group rather than in individual members of these groups because it is difficult to isolate individuals who contributed to the conservation or preservation of these resources. In addition to this practical consideration, it is appropriate to vest property rights in the various indigenous groups because no single individual singlehandedly preserved and conserved the plant genetic resources.

Second, vesting property rights in such groups is preferable to vesting them in the nation-state. The geographical sizes of various African countries and the drawing of their national boundaries without due regard to anthropological considerations makes the African nation-state an inappropriate entity in which to vest these proprietary rights. Groups living in a certain climatic region should be responsible for undertaking the conservation and preservation of plant genetic resources in that region. Members of these groups should exercise property rights in the resources present in their localities because equity demands that each person be rewarded according to his efforts.

Benefits stemming from a plant variety preserved by communities in particular regions should not accrue to communities that never participated in its preservation and conservation, even though these communities may be found within the same country. Theoretically, no difference exists between such other communities and foreign countries. One may perceive each group or community "as an author who originates a culture from resources that come from within and thus lays claim to exclusive possession of the expressive works that embody its personality. ${ }^{\text {n182 }}$

${ }^{182}$ Coombe, supra note 38 , at 264. 
In addition, vesting plant genetic resources in groups permits the group to take control of its own destiny because it allows the possession of the plant genetic resources in the context in which they were nurtured, preserved, and rendered useful to humanity. This position mirrors policies found in historic preservation law, which "recognizes group interest in property for the purposes of developing a sense of community, ${ }^{183}$ focusing on the propinquity of plant genetic resources to the group that nurtured them. This perspective squarely places plant genetic resources under the Convention on the Means of Prohibiting and Preventing the Illicit Import, Export and Transfer of Ownership of Cultural Property. ${ }^{184}$ Under this Convention, plant genetic resources come within the definition of "cultural property," rare collections and specimens of flora relating to history. ${ }^{185}$

An additional argument supporting vesting of plant genetic property rights in groups stems from the relationship of these resources to the environment. Plant genetic resources are similar to cultural property, associated with the group or community that has nurtured them. This association is a human-environment symbiosis, a relationship between a thing and its context. Ethnobotany should thus determine ownership of the resources, vesting ownership in the group or communities that cared for the resources. Assigning ownership of plant genetic resources in this manner assures sensitivity to both the nuances of the particular historical situation in which the claim to these resources arises and the distinctive needs of the groups involved. This "call to context is a call to consider the structures of power in society" 186 that nurtured and preserved the plant genetic resources. Moreover, justification for vesting proprietary rights to plant genetic resources for groups finds support in the idea that groups have intrinsic

${ }^{183}$ Moustakas, supra note 83, at 1193.

${ }^{184}$ See Convention on the Means of Prohibiting and Preventing the Illicit Import, Export, and Transfer of Ownership of Cultural Property, Nov. 14, 1970, 823 U.N.T.S. 231 (adopting historic preservation model).

${ }^{185}$ In Article 1, the Convention defines cultural property to include: "(a) [r]are collections and specimens of fauna, flora, minerals and anatomy, and objects of palaeontological interest; (b) property relating to history, including the history of science and technology. ... Id. at 234.

${ }^{183}$ Coombe, supra note 38, at 270 (citation omitted). 
rights and 'that these rights often are intertwined with groups' relations to history and objects .... .

Vesting property rights to plant genetic resources in groups and communities encounters a difficulty attributable to human mobility. When individual members of groups and communities move and intermingle with other communities, it becomes difficult to identify the specific communities that conserved and preserved the plant genetic resources in question. This flexibility of group boundaries and subsequent difficulty in ascertaining members of the group should not prevent discussion of vesting proprietary rights in groups. Furthermore, one commentator observes that deciding specific disputes among rival group claimants requires "a vibrant conception of group rights." 188

Arguably, the vesting of property rights in groups and communities will promote conservation of biodiversity, providing economic incentives to conserve and protect areas in which unknown but potentially valuable species are located. ${ }^{189}$ However, the converse is also true. Vesting proprietary rights in groups implies that, theoretically, every individual member of the group owns plant genetic resources, while in reality, no one does. Just as with the concept of a common heritage of mankind, little or no incentive exists, save for altruism, to incur costs to conserve and protect unique and endangered species.

An arguable flaw in vesting plant genetic resources in groups is its potential impact on the incentive to advance biotechnological innovations. Proponents of a European, individualistic concept of property could contend that the prospect of monopoly returns and economic rent accruing to an individual is a strong incentive for innovation in biotechnology. Consequently, vesting plant genetic property rights in the group may undermine this economic incentive and limit advances in biotechnology. This argument is fallacious because groups and communities in Africa and other developing countries preserved and nurtured these resources in the

${ }^{187}$ See Moustakas, supra note 83, at 1185 (distinguishing claims for fungible property from claims for property in grouphood).

${ }^{188}$ Id. at 1187.

${ }^{180}$ See Margulies, supra note 1, at $\$ 46$ (listing benefits that could accrue if intellectual property rights extended to germplasm located in developing countries). 
past without monetary incentives. ${ }^{190}$ Furthermore, no conclusive empirical evidence exists showing a positive correlation between economic incentives, existence of breeders' protection, and advances in biotechnology.

Thus, it is apparent that international law has yet to develop an acceptable formula to resolve the issue of ownership of ex situ plant genetic resources. It is time for international law to positively address this issue. In relation to in situ resources, the Biodiversity Convention marks a discernible evolution of international legal standards in its recognition that nations exercise sovereign rights over plant genetic resources within their borders and deserve to share in the benefits accruing from the exploitation of these resources. The Convention rejects the orthodox classification of plant genetic resources as a common heritage of mankind. By adopting an approach that recognizes intellectual property entitlements both in discovered and protected natural plant germplasm, the Convention heralds a new direction for analyzing plant genetic resources under international law.

For developing countries, given the difficulties of utilizing an individualistic conception of property to claim a share of profits emanating from their valuable plant genetic resources, it may well be time for these countries to salvage the ethnobotanical information on their plant breeding and selection activities. Such action will fortify their case for selection and preservation of plant genetic resources and thus furnish a solid basis for claiming proprietary rights over plant genetic resources.

${ }^{100}$ Margery L. Oldfield \& Janis B. Alcorn, The Conservation of Thaditional Agroecosystems, BIOscience, Mar. 1987, at 199, 201. 
Journal of Intellectual Property Law, Vol. 2, Iss. 1 [1994], Art. 4 